\section{Survey Investigasi Desain Air Baku di Pegatan Kab.}

\section{Katingan}

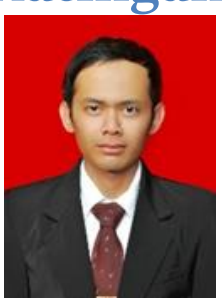

\section{Adi Setiawan, ST}

Lahir di Pasirmas, 8 Maret 1989, Alumni Universitas Lambung Mangkurat, saat ini bekerja di perusahaan kontraktor Pandji Group.buletinppi@ulm.ac.id

\title{
Pendahuluan
}

Buletin ini berisi tentang pengalaman penulis dalam menangani pekerjaan Survey Investigasi dan Desain (SID) Air Baku untuk keperluan air minum di Pegatan Kabupaten Katingan. Pada buletin ini memaparkan pengalaman penulis dalam penentuan lokasi dan sumber air baku yang akan digunakan.

Maksud dan tujuan penulisan buletin ini ialah untuk berbagi pengalaman tentang metode pelaksanaan dari pekerjaan SID Air Baku di Pegatan Kab. Katingan.

\section{Hasil Kerja}

\section{DATA PEKERJAAN}

Nama Pekerjaan : Survey Investigasi dan Desain Air Baku di Pegatan Kabupaten Katingan

Tahun Anggaran : 2012

Pemilik Pekerjaan : Dinas Pekerjaan Umum Bidang Sumber Daya Air Provinsi Kalteng

Lokasi : Desa Pegatan Kabupaten Katingan Kalimantan Tengah

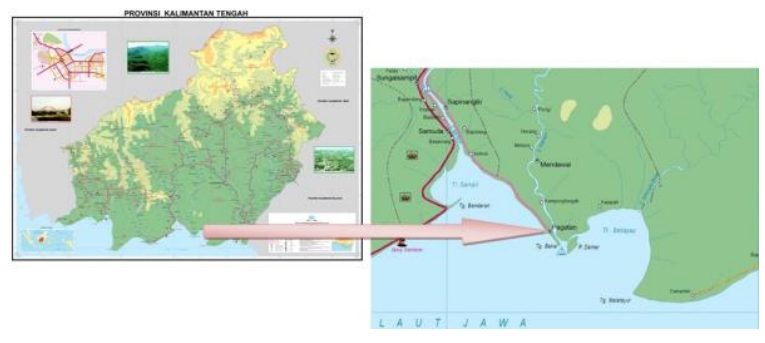

Gambar 1. Lokasi Pekerjaan

Desa Pegatan terletak di muara sungai Katingan di mana air sungainya langsung berhubungan dengan air laut Jawa sehingga air sungainya tidak bisa digunakan sebagai air minum. Sumber air baku yang selama ini digunakan adalah air hujan dan air sumur dangkal yang jumlahnya belum bias mencukupi kebutuhan peduduk desa Pegatan.

Air merupakan sumber daya alam yang sangat diperlukan oleh manusia sepanjang masa dan menjadi bagian dari kebutuhan dasar manusia yang sangat penting. Di Desa Pegatan Kabupaten Katingan pada musim kemarau panjang persediaan air untuk keperluan minum tidak mencukupi kebutuhan. Maka pada tahun 2012 dilakukan kegiatan pekerjaan Survey Investigasi dan Desain Penyediaan Air Baku di Pagatan Kabupaten Katingan.

www.buletinppi.ulm.ac.id

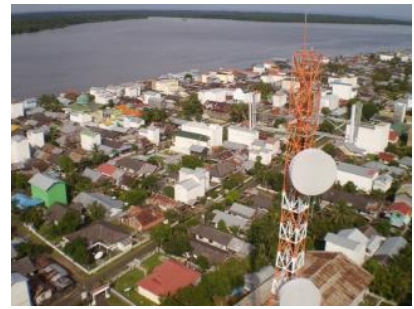

Gambar 2. Gambaran Umum Pegatan

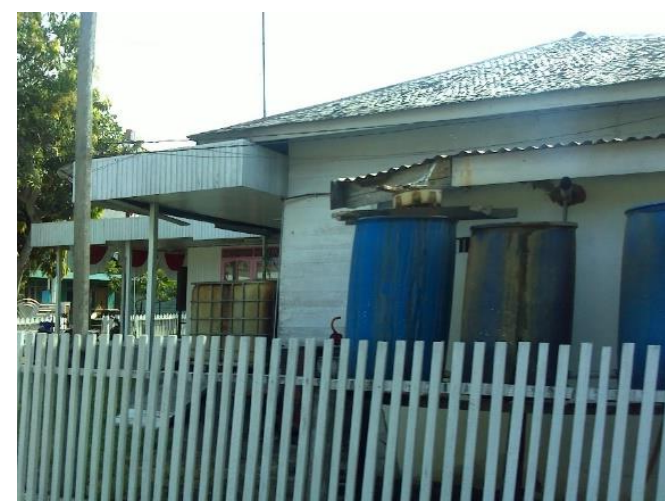

Gambar 3. Sumber air dari penampungan air hujan

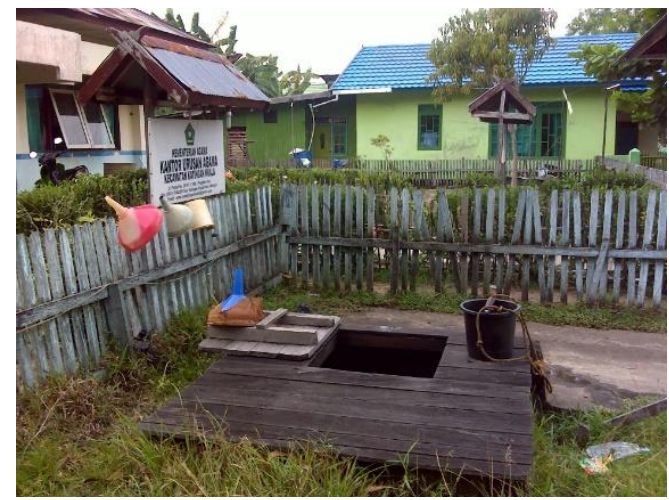

Gambar 4. Sumber air dari sumur dangkal

Atas pertimbangan di atas maka pihak pemerintah Provinsi Kalimantan Tengah melalui dinas Pekerjaan Umum ingin melakukan Survey Investigasi dan desain air baku untuk memenuhi kebutuhan penduduk desa Pegatan. 
Ditunjuk sebagai pemenang lelang dan peyedia jasa Konsultan PT. Adiya Widyajasa.

\section{Pelaksanaan Pekerjaan}

1. Survey

Survey Topografi dilakukan untuk mengetahui elevasi tertinggi dari desa pegatan yang tidak terpengaruhi rembesan air laut pada cadangan air tanahnya. Sedangkan survey hidrologi dilakukan untuk mengetahui curah hujan rerata tahunan dan juga menghitung curah hujan andalan.pemenang lelang dan peyedia jasa konstruksi PT. Pandji Bangun Persada.

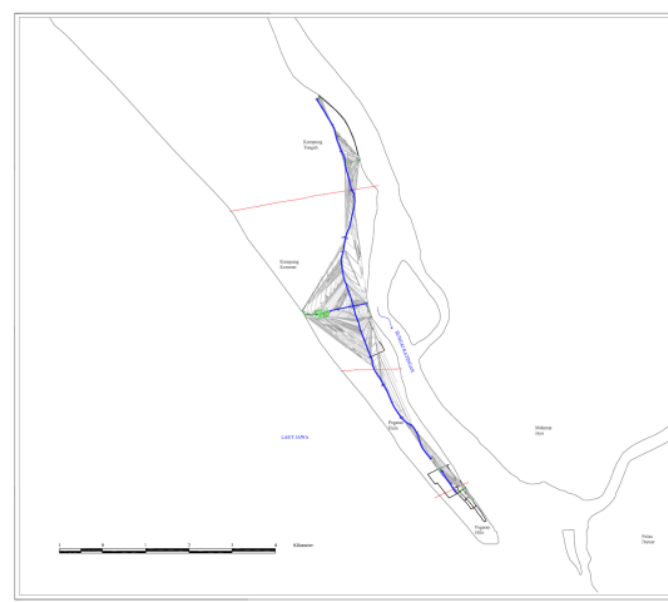

Gambar 5. Hasil survey topografi

Dari gambar 5. Dapat diketahui elevasi tertinggi terletak di desa Keramat, lokasi inilah yang nantinya dijadikan lokasi pengambilan sumber air baku. Di daerah ini struktur tanahnya lebih keras dan air laut tidak mempengaruhi kualitas air tanah sehingga dapat dijadikan lokasi pembuatan sumur/kolam pengambilan air tanah.

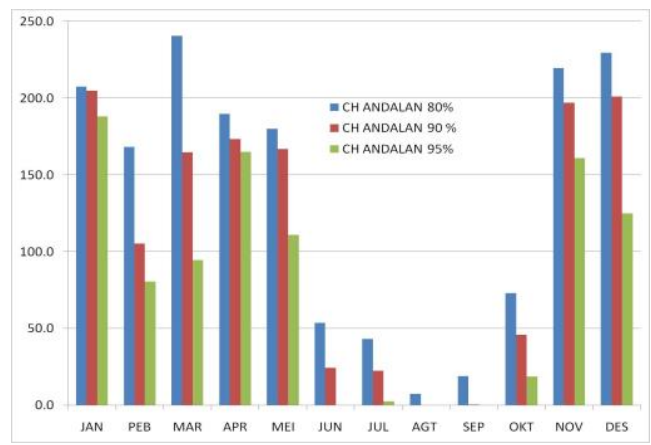

Gambar 6. Diagram Curah Hujan Andalan

Dari diagram di atas dapat deketahui bahwa pada bulan Agustus sampai September desa pegatan mengalami musim kemarau yang mengakibatkan air baku susah didapat. Pada bulan Agustus inilah diadakan survey lokasi air baku.

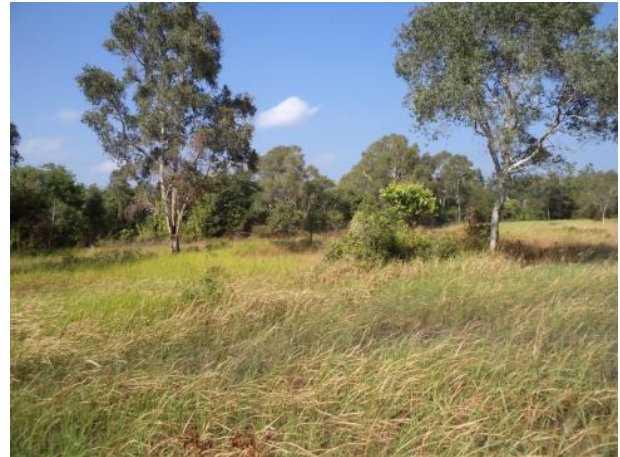

Gambar 7. Lokasi Survey Air Baku

Setelah ditemukan lokasi pengambilan air baku, dilakukan survey mekanika tanah untuk mengetahui jenis tanah dan daya dukung tanah. Survey mekanika tanah yang digunakan adalah hand bor dan sondir.

Tabel 1. Hasih Bor Log

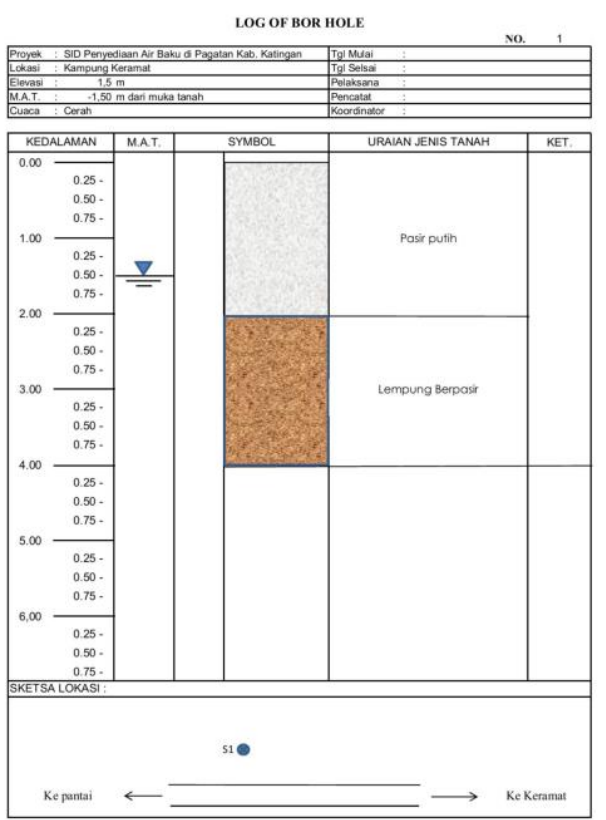

Dari tabel 1 dapat diketahu jenis tanah yang ada dilokasi pengambilan air baku di mana pada kedalaman lebih dari 2 meter struktur tanah sudah lunak. Sehingga pembuatan sumur untuk air baku hanya bisa pada kedalaman 1 sampai 2 meter. 


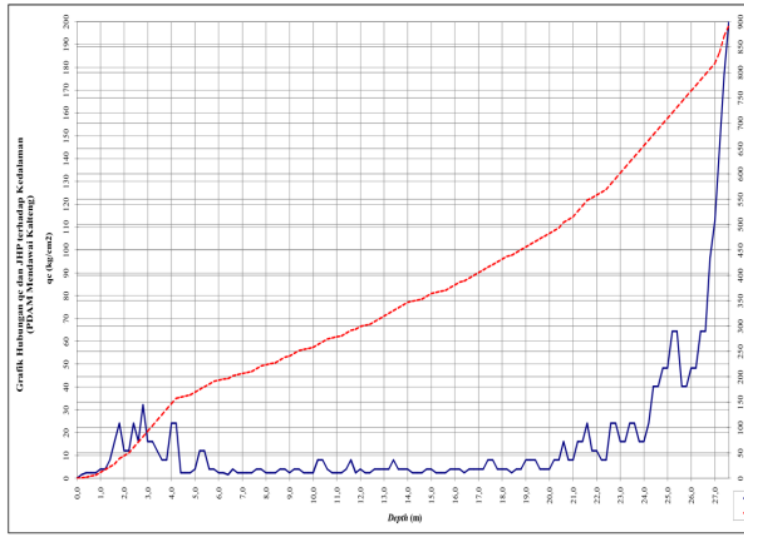

Gambar 9. Grafik Uji Sondir

2. Investigasi

Setelah didapatkan lokasi yang tepat untuk melakukan penelitian sumber air baku, maka dilaksanakanlah investigasi ketersediaan air baku di daerah tersebut. Metode yang digunakan adalah dengan membuat sumur-sumur dangkal sebanyak 4 buah.

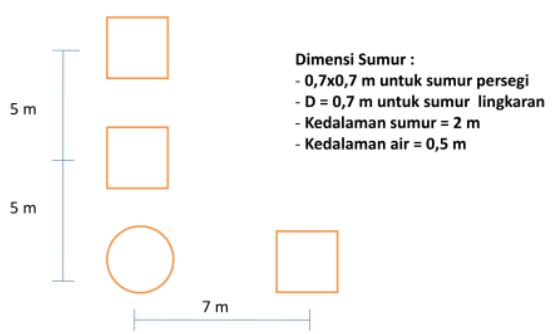

Gambar 10. Formasi pembuatan sumur dangkal

Formasi L dibuat dengan maksud mengetahui profil muka air tanah memanjang maupun melintang. Tahap selanjutnya adalah pengujian sumur dengan cara memompa (Pumping Test) isi air dalam sumur lalu mencatat waktu air kembali kemuka air semula. Pegujian dilakukan sebanyak tiga kali percobaan untuk satu formasi sehingga didapat hasil yang akurat.
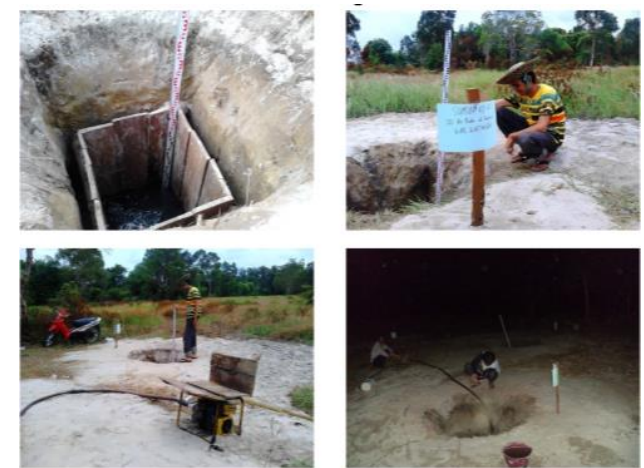

Gambar 11. Tahap pengujian sumur dangkal

Hasil pengujian sumur dapat dilihat pada tabel dibawah.

Tabel 2. Hasil Pumping Test sumur dangkal

\begin{tabular}{|c|c|c|c|c|c|c|c|}
\hline \multirow{2}{*}{\multicolumn{2}{|c|}{ 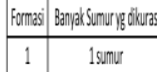 }} & \multirow{2}{*}{$\frac{\text { No. Sumvrygakinas }}{1}$} & \multirow{2}{*}{$\frac{\text { (eddamanhir(m) }}{0,5}$} & \multirow{2}{*}{ 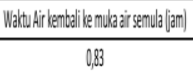 } & \multirow{2}{*}{ 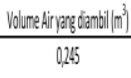 } & \multirow{2}{*}{$\frac{\|_{s}}{0,081667}$} & \multirow{2}{*}{$\frac{m^{3} / \mid h a i n}{607} 7,056$} \\
\hline & & & & & & & \\
\hline & & 2 & 0,5 & 0,83 & 0.25 & 0,088667 & 7,566 \\
\hline & & 3 & 0,5 & 1,0 & 0,192 & $0,0,5324$ & 4,616 \\
\hline & & 4 & 0,5 & 0,77 & 0,245 & 0,088780 & 7,60 \\
\hline \multirow[t]{4}{*}{2} & Lonu & $\log 2$ & 0,5 & 0,2 & 0,40 & 0,14845 & 12828 \\
\hline & & $2 \mathrm{~d} n \mathrm{n} 3$ & 0,5 & 1,0 & 0,437 & 0,121249 & 10,46 \\
\hline & & 36014 & 0,5 & 1,00 & 0,437 & 0,121299 & \\
\hline & & 100014 & 0,5 & 0,55 & 0,490 & 0,1425275 & 12,3 \\
\hline \multirow[t]{3}{*}{3} & 3smur & $1,2,20033$ & 0,5 & 1,5 & 0,682 & 0,126356 & \\
\hline & & $2,3,6020$ & 0,5 & 1,5 & 0,682 & 0,126356 & 10997 \\
\hline & & 1,3,600n 4 & 0,5 & 1,5 & 0,682 & 0,126356 & 109. \\
\hline \multirow[t]{3}{*}{4} & 4 senur & Percociann! & 0,5 & 2 & 0,927 & 0,128755 & 11,128 \\
\hline & & Peroctann? & 0,5 & 2 & 0,927 & 0,12885 & 11,128 \\
\hline & & Percocann 3 & 0,5 & 2 & 0,927 & 0,12875 & 11,12 \\
\hline
\end{tabular}

Dari table 2 dapat diketahui semakin banyak jumlah sumur yang dipompa, maka semakin lama waktu yang dibutuhkan untuk mengembaliakan elevasi muka air ke ketinggian semula.

Formasi pemompaan jumlah sumur yang maksimal adalah dengan memompa dua sumur dan membiarkan dua sumur yang lain tidak dipompa. Sehingga jumlah air yang didapat lebih banyak dan waktu kembalinya elevasi muka air ke ketinggian semula lebih cepat.

3. Desain

Dari percobaan yang telah dilakukan dapat diketahui lokasi pengujian terdapat sumber mata air berupa air sumur dangkal. Untuk desain rencana yang akan dilakukan adalah dengan membuat sumursumur dangkal yang akan dipompa bergantian sesuai dengan zona yang ditentukan lalu ditampung di kolam yang nantinya akan didistribusikan ke rumah penduduk. 


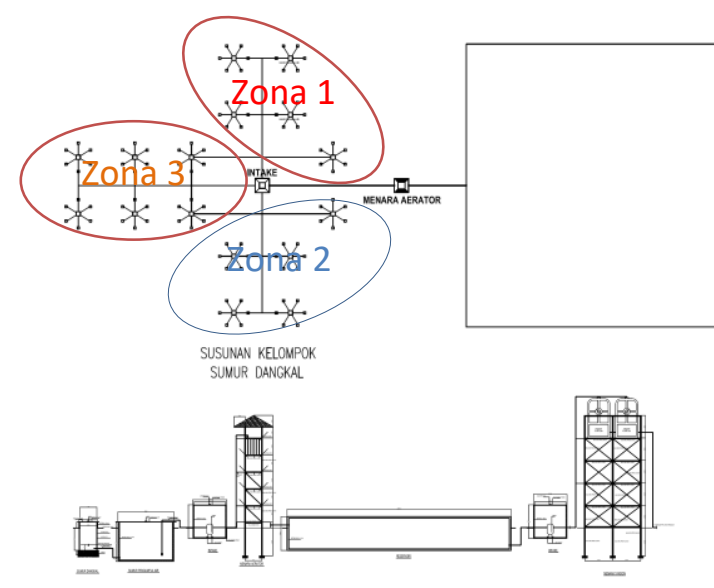

Gambar 12. Desain Bangunan Air Baku

\section{Kesimpulan}

1. Sumber air baku yang dapat digunakan hanyalah dari air tanah dangkal.

2. Desain yang akan digunakan adalah dengan membangun sumur-sumur dangkal yang dipompa secara bergantian lalu ditampung ke dalam kolam penampungan kemudian dialirkan ke rumah penduduk.

3. Air sungai tidak dianjurkan untuk bahan air baku.

\section{Ucapan Terimakasih}

Ucapan Terimakasih kami sampaikan kepada pihakpihak yang berperan dalam kelancaran dan keberhasilan pelaksanaan pekerjaan ini yaitu :

1. ALLAH Subhanahuwata'ala, atas segala kemudahan dan keselamatan yang telah diberikan.

2. Pemilik pekerjaan Dinas Pekerjaan Umum Provinsi Kalimantan Tengah.

3. Dewan Direksi PT. Adiya Widyajasa.

4. Semua pihak yang sudah bahu-membahu bekerjasama menyelesaikan pekerjaan ini.

\section{Referensi}

1. Chow, V. T.1992. Hidraulika Saluran Terbuka. Erlangga. Jakarta

2. Harto. Br, Sri. 1993. Analisa Hidrologi. PT. Gramedia Pustaka Utama. Jakarta.

3. Hartono. 2005. Statistik untuk Penelitian. Pustaka Pelajar Offset. Yogyakarta.

4. Subarkah, Imam, Hidrologi untuk Perencanaan Bangunan Air. 1980. Ide Dharma. Bandung. 